\title{
THE DIET OF THE NEPHRITIC.*
}

\author{
By E. C. WARNER, M.D., M.R.C.P. \\ (Hon. Asst. Physician, Charing Cross Hospital; Hon. Physician, Children's Dept., Miller \\ General Hospital.)
}

With inflammation of the kidney, as with inflammation or degeneration of other parts of the body, our ideas of treatment have been immensely clarified as a result of knowledge of the normal physiology of the organ, and recent advances in biochemistry have indicated the extent and nature of the pathological process: thus in some types of renal disease, nitrogen retention is the chief factor, in others, the difficulty is mainly one of excretion of salt and water. By a careful correlation of these different aspects, we are able to give a rational line of treatment, and the dietetic side of this is often of the greatest importance.

It is most convenient to discuss the different forms of nephritis under the headings of acute, subacute, and chronic nephritis.

\section{Acute Nephritis.}

Acute inflammation of the kidneys exists in two main forms, the acute focal and the acute diffuse types. Acute focal nephritis is especially met in children in whom, within I to 6 days following an acute streptococcal infection, there is marked hæmaturia, but without signs of renal failure. It is believed that only a small percentage of renal glomeruli and tubules (nephrons) is affected, the remainder being more than sufficient to carry on the normal functions of the kidneys. With the brisk hæmorrhage from certain of the nephrons, the amount of albumin is only such as would be expected from the amount of bleeding; there is a normal volume of urine, the blood pressure does not rise, and the blood urea remains at a normal figure. The prognosis of these cases is excellent as the inflamed nephrons are not called upon to secrete any urine. Apart from dealing with the focal cause of the condition, dietetic treatment is not required, and once the temperature has subsided, it is usual to give a full diet forthwith.

Acute diffuse glomerulo-tubular nephritis is an entirely different proposition. Here the whole kidney is involved, and signs of renal failure are manifest. With an onset usually in the second or third week after an acute streptococcal infection it is believed that the kidneys are affected by the toxins of the bacteria, rather than by small emboli of the bacteria themselves. Hence the kidneys fail to perform their normal functions; with the retention of sodium chloride and water, œedema develops and the urinary output falls: the failure in nitrogenous excretion leads to a raised blood urea and blood phosphate (with corresponding diminution in the urinary content), thus giving rise to lassitude, headache and a raised blood pressure: while the renal toxæmia is shown by the amount of albumin present being much more than would be expected from the amount of bleeding. During the acute stage the kidney is unable to deal with the demands normally made upon it, and renal rest is essential. Hence the patient is kept in bed, (this having the effect of lowering the general metabolism) and he should be given a diet which puts as little strain on the kidneys as possible. The fluid intake should be such as will satisfy the requirements of the skin and lungs, and leave little to be excreted by the kidneys: protein and sodium chloride should be eliminated from the diet so far as

* Being one of a series of lectures on Diet and Dietetics delivered under the auspices of the Fellowship of Medicine on December 5 th, 1934. 
is practicable, until the more acute stage has passed, but, on the other hand, sugar and other carbohydrates and a certain amount of fat may be allowed, as these will satisfy hunger and yet impose no renal strain. Lastly, such foods as are given should be such as will form alkalies in the body, for not only is the alkali reserve of the blood lowered by the retention of acid bodies, but it is probable that inflamed renal cells are further damaged by acid secretion in the same way that the stomach is irritated by acid in the presence of inflammation or ulceration. The older plan of giving mainly a milk diet is unsound, as $I_{\frac{1}{2}}$ pints of milk a day contain 37 grammes of protein and $\mathrm{I}_{2} \frac{1}{2}$ grammes of sodium chloride. The best plan is to give a diet such as the following:

STAGE I.

\section{Acute Nephritis.}

I $\frac{1}{2}$ pints of fluid a day; water, barley water, Imperial drink, glucoseorangeade or lemonade with glucose added in the proportion of $4-6$ ozs. per pint, grape-juice or tomato-juice, and toffee if acceptable.

This is continued until the hæmaturia has diminished, the blood pressure has fallen and the "critical diuresis" set in-usually a matter of 3 to 4 days. The diet may then be increased to-

STAGE II.

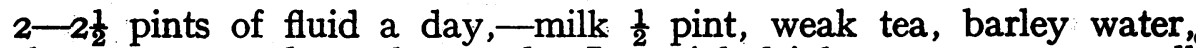
glucose-orangeade or lemonade, Imperial drink, I orange, I smallo tomato, grapes, stewed fruit, 2 ozs. of brown bread with fresh butter, 2 ozs. of potatoes, porridge, milk puddings, honey, marmalade, jam, and $\frac{1}{2}$ oz. of cream. (Fruit and vegetables to count as an equivalent weight of water.)

About the roth-I4th day it is usually possible to increase still further to-

STAGE III.

3 pints of fluid a day-milk I pint, weak tea, barley water, orangeade or lemonade, Imperial drink, oranges, grapes, tomatoes, ad lib., stewed fruit, milk puddings, cereal foods such as grape-nuts, porridge, bread, cakes, fresh butter, cream, honey, jam, marmalade, steamed fish, potatoes, greens and salads.

Foods to be avoided.

ENTIRELY FORBIDDEN. Soups, bovril, beef-tea, liver, brains, sweetbread, alcohol, acid foods such as vinegar, and spices.

AVOIDED UNTIL CEDEMA HAS DISAPPEARED. Salt (in foods and at table).

AVOIDED UNTIL BLOOD UREA AND BLOOD-PRESSURE LOWERED. Meat, bacon, ham and poultry.

The above scheme is of general application, but should the daily output of urine continue to fall in the first few days, and the blood urea mount above Ioo mgms. per cent., then rather more fluid should be given to control these. At times the effects of these dietetic restrictions may seem to be disappointing, but their value will soon be demonstrated if they are grossly departed from. 


\section{Subacute Nephritis.}

Subacute Nephritis is usually considered to be present when the œedema and the presence of red cells in the urine are demonstrable after the end of two months. Sometimes this stage is reached insidiously without the patient ever having had manifest acute nephritis: in other cases the acute stage is so mild that it is only when the œdema becomes alarming that the patient comes under treatment. Broadly speaking, there are two extremes of the clinical picture, (I) the œedematous (or nephrotic) variety; this is accompanied by a diminished volume of urine, copious albuminuria, and often the blood shows lipæmia. This variety may subside completely, or may pass on to the chronic type with a small granular kidney, with the gradual development of uræmia. (2) A low grade variety of infection with frequent relapses, where the presence of active disease can be shown by the presence of epithelial casts and red blood cells in the urine, perhaps with periods of temporary cedema, and in which again uræmia is liable to ensue sooner or later. The treatment depends essentially on the clinical picture and the biochemical findings. In the œdematous variety the kidney is unable to secrete sodium chloride and water, the urinary volume remains at a low figure, but, on the other hand, the amount of albumin lost through the kidneys per day may amount to Io, 20, or even 25 grammes, as measured in Esbach's albuminometer. The cedema is due to at least two of these factors: the salt and water are retained in the body: they are not kept in the blood for the blood volume and chloride content are normal, but are poured out into the serous cavities and tissue spaces. Albuminuria leads to a depletion of blood colloids: the osmotic pressure of the blood proteins is normally due largely to the plasma-albumin rather than to the plasmaglobulin, and so the osmotic pressure falls in the face of the great albuminuria. The blood is not able to retain or to attract water from the tissue spaces, and so further œdema ensues. The rational line of therapy is therefore to limit the amount of water to the quantity which the kidneys excrete per day, and salt should be avoided as far as possible: at the same time, to make up for the enormous albuminuria and to furnish sufficient to replenish the lowered blood albumin, the protein intake should be of a high order. The lipæmia which is so often present, though not fully understood, is often taken to mean that the tissues are overloaded with lipoid substances, and on this account the animal fat intake is reduced. Many of our ordinary articles of diet contain a considerable percentage of salt.

\section{Salt content of Foods.}

Sea-fish, egg-white and ordinary bread contain $\ldots \quad 0.5 \% \mathrm{NaCl}$

Milk, chicken, steak, mutton, veal, lamb, and egg$\begin{array}{llllllll}\text { yolk contain } \ldots & \ldots & \ldots & \ldots & \ldots & \ldots & 0.16 \% & \mathrm{NaCl}\end{array}$

While on the other hand

Potatoes, oysters, fresh-water fish, stewed fruit, oatmeal, salt-free butter, and bread made without salt contain less than $\quad \ldots \quad \ldots \quad \ldots \quad \ldots \quad .06 \% \quad \mathrm{NaCl}$

Karell's diet was constructed of foods containing a low percentage of sodium chloride, while Epstein's diet was constructed to contain a high proportion of protein (I20-240 grms.,) and a reduced quantity of fat (20-40 grms.,). As we are now dealing with a more prolonged condition, it is very important that the diet should be of sufficient calorie value and should contain an adequate amount of the essential food substances. Infection of the œdematous tissues occurs readily 
enough, and pneumococcal, streptococcal and other such infective disorders are of serious import. Recently R. A. Peters has suggested that vitamin B may be inadequate in many of the diets usually given, and this in itself may contribute to further œdema. A diet which will meet these requirements is as follows :-

\section{Diet with High Protein and Low Fat and NaCl Contents.}

The total fluid intake should be a few ounces more than the urinary output, such foods as fruit and vegetables counting as contributing their weight of water to the total intake.

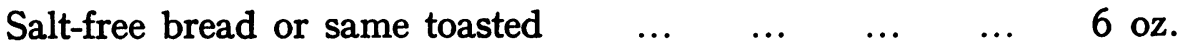

Oysters, white fish-preferably fresh-water fish $\ldots . \quad \ldots \quad 6$ oz.

$\begin{array}{lllllllll}\text { Salt-free butter } & \ldots & \ldots & \ldots & \ldots & \ldots & \ldots & \ldots & \frac{1}{2} \text { oz. }\end{array}$

Skimmed milk, flavoured with weak tea or coffee to I pint.

Mutton, veal, lamb, chicken and lean ham ... $\quad \ldots \quad$... Io oz.

$\begin{array}{llllllllll}\text { Sugar } & \ldots & \ldots & \ldots & \ldots & \ldots & \ldots & \ldots & \ldots & 2 \text { oz. }\end{array}$

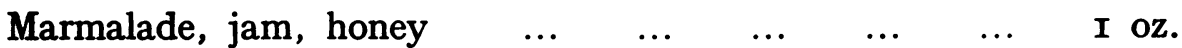

Rice or other cereal made into milk puddings $\quad \ldots \quad \ldots \quad$ I oz.

or taken when toasted as flaked cereals or oatmeal ... I oz.

Grapes, tomatoes, apples, stewed fruit $\ldots \quad \ldots \quad \ldots \quad$ Io oz.

\section{Approximate Values.}

\begin{tabular}{lccccccc}
\multicolumn{2}{l}{ Protein content } & $\ldots$ & $\ldots$ & $\ldots$ & $\ldots$ & I50 \\
Fat $\ldots$ & $\ldots$ & $\ldots$ & $\ldots$ & $\ldots$ & $\ldots$ & 45 &, \\
Carboh. & $\ldots$ & $\ldots$ & $\ldots$ & $\ldots$ & $\ldots$ & 300 &, \\
NaCl & $\ldots$ & $\ldots$ & $\ldots$ & $\ldots$ & 2.5 & -3.0 &, \\
Calories & $\ldots$ & $\ldots$ & $\ldots$ & $\ldots$ & $\ldots$ & $\ldots$ & 2, I00
\end{tabular}

If any benefit is to be obtained with such a diet, it should show itself within 6-8 weeks: and if no improvement is found within this period, it is useless to continue it. In such a case, an ordinary diet can be resumed, although in any case it is wise to limit the total fluid and the salt intake, particularly as these entail no hardship to the patient.

It is unwise to use such a high protein diet if the blood urea is much raised before the diet is commenced, or if the urea concentration test gives a value of less than 2 per cent. ; in any case, weekly estimations of the blood urea are desirable, in case it is found to be rising with such a diet. In either of these cases, the Karell diet can still be used.

DAYS I-7.

\section{Karell Diet.}

Milk 7 oz. at 8 a.m., I2 noon, 4 p.m. and 8 p.m.

Total salt is I.3 grms.

DAY 8.

Add at Io a.m. a softly cooked egg and one slice of toast.

Total salt is $1.78 \mathrm{grms}$. 
DAY 9.

Add 2 oz. of vegetables such as asparagus, celery, cauliflower or carrot, and two teaspoonfuls of cornflour to the milk taken at noon, to form milk soup. Add one slice of toast at 4.30 p.m.

Total salt is $\mathrm{r} .89 \mathrm{grms}$.

DAYS I0-I2.

Add one egg, I oz. rice (weighed raw) and $2 \mathrm{oz}$. of the vegetables.

Total salt is $2.4 \mathrm{I}$ grms.

For the cases of subacute nephritis unaccompanied by much œdema, the high protein diet is not necessary, and usually it is wisest to use the Stage II and Stage III diets already mentioned for acute nephritis. For the condition of pregnancy nephritis, where there is usually some degree of nitrogen retention as well as of œdema, the dietetic treatment should again be on the lines of that outlined for acute nephritis.

\section{Chronic Nephritis.}

In chronic nephritis we are dealing with a badly damaged kidney, which cannot recover to any extent. We are therefore called upon to protect the remaining kidney tissue and make it last as long as possible. Sooner or later renal failure will become complete, and uræmia ensue, but with careful management, the day on which this occurs will be delayed by many months or years. In the management of such a case, the diet is one of the most important measures at our disposal. In the earlier stages there is often polyuria and a high blood pressure. These are largely protective and help the kidneys to maintain a satisfactory excretion of nitrogen bodies. Therefore treatment designed to diminish these is definitely bad. Before constructing a diet for such a patient, it is important to have certain biochemical information, viz.: the level of the blood urea, and also the reaction of the patient to drinking I pint of water. If this latter results in a good diuretic effect, a rather larger amount of fluid may be allowed. If the blood-urea is over roo mgms. per cent., the initial diet should be composed almost entirely of carbohydrate foods, with fruit and vegetables for the first few days. It is unwise to limit the total fluid intake too strictly, as this may precipitate uræmia instead of alleviating it.

Diet for Chronic Nephritis with Nitrogen Retention. (Blood Urea over $100 \mathrm{mgms.} \%$ ).

Total fluid intake $2 \frac{1}{2}-3$ pints per day:-

Weak tea, barley water, lemonade, orangeade, Imperial drink.

Also glucose in the proportions of 4-6 ozs. to the pint, with grape juice or tomato juice: cream $\frac{1}{2}-I$ oz. daily.

After 3 or 4 days of such a régime, usually the blood urea has fallen to lower limits and then a low protein diet should be given. Chittenden and others have shown that it is possible to maintain nitrogenous equilibrium on a diet containing 30 grammes of protein a day, and this certainly applies when we are dealing with an elderly patient whose requirements are lower than those of a more active and younger individual. So long as the blood urea remains over $80 \mathrm{mgms}$. per cent., such a low protein diet is desirable. 
Diet for Chronic Nephritis with Nitrogen Retention. (Blood Urea over 80 mgms. \%).

Total fluid intake $2 \frac{1}{2}-3$ pints of fluid daily, consisting of weak tea or coffee, milk ( $\frac{1}{2}$ pint), lemonade, orangeade: bread or biscuits $(5 \mathrm{oz}$.$) ,$ butter $(2 \mathrm{oz}$.), porridge or cereal foods such as flaked wheat or flaked rice ( 2 oz.), milk puddings, cream ( $\mathrm{I}$ oz.) cake: jam or honey or marmalade $\left(\frac{1}{2} \mathrm{oz}\right.$.), sugar $(2 \mathrm{oz}$.$) , green vegetables and salads ad lib.:$ potatoes $(5 \mathrm{oz}$.) ; fish or meat or chicken $(2 \mathrm{oz}$.) or I egg.

Approximate content:-

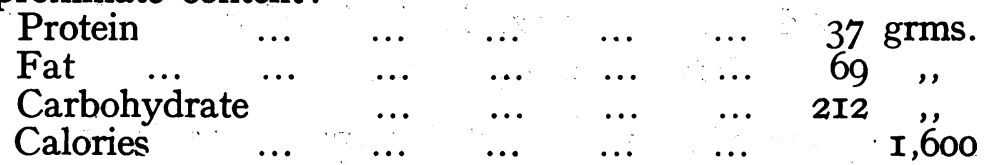

UNRESTRICTED FOODS. Green vegetables: salads: fruits: sugar: honey: jam: arrowroot: butter.

FOODS TO BE AVOIDED. Condiments : spices : meat extracts : brains : liver: sweetbread.

Alcohol is probably better avoided, but if it is allowed, weak whisky and water or soda water are probably best. It will be noticed that salt is not unduly restricted, unless œdema happens to be present also, which is rare. Although it is wise to disallow extra salt, there is probably no need to limit it otherwise.

When the blood urea lies between 40 and 80 mgms. per cent., then a higher protein diet may be given:-

\section{Diet for Chronic Nephritis with Nitrogen Retention.}

(Blood Urea between 40 and 80 mgms. \%).

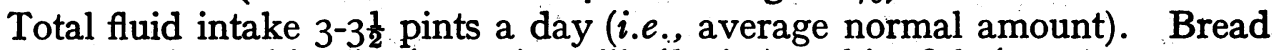
or cake or biscuits (Io oz.) : milk ( $\frac{1}{2}$ pint) : white fish ( 4 oz.) or I egg : meat or chicken (3 oz.).

UNRESTRICTED FOODS. Green vegetables: potatoes: salads : fruit: sugar: honey: jam : marmalade : oatmeal: cereal foods such as flaked wheat or flaked rice or other cereal preparations: milk puddings: butter: cream.

FOODS TO BE AVOIDED. Condiments: spices : meat extracts : brains : liver: sweetbread.

$$
\begin{array}{cccccc}
\text { Approximate protein value } & \ldots & \ldots & 72 & \text { grms. } \\
,, & \text { calorie value } & \ldots & \ldots & \ldots & 2,200
\end{array}
$$

In any patient in whom there is a tendency for the blood urea to rise over a period of months, it is a very good plan to give a day's semi-starvation a week. This will involve the avoidance of all protein and living on a fruit and vegetable diet during a period of twenty-four hours. It is sometimes stated that the intake of sodium chloride should be restricted in chronic nephritis. It is not usual to do this unless œdema is present, and in the cases with uræmic tendency it is probably wise to allow a normal intake.

Although the purpose of this lecture is to describe dietetic treatment which may be of considerable aid in controlling cedema or nitrogen retention in the different types of nephritis, it is very unwise to regard this as the only form of treatment necessary; but as the dietetic aspect is so often neglected in general practice, the principles set out above may prove of value as a guidance to those of us who are called upon to deal with nephritic cases. 